\title{
ResearchOnline@JCU
}

This is the Accepted Version of the following reference:

Takahashi, Katsu, Kiso, Honoka, Saito, Kazuyuki, Togo, Yumiko, Tsukamoto, Hiroko, Huang, Boyen, and Besho, Kazuhisa (2013) Feasibility of gene therapy for tooth regeneration by stimulation of a third dentition. In: Gene therapy: tools and potential applications. InTech, Rijeka, Croatia, pp. 727-744.

http://dx.doi.org/10.5772/50194 
open science | open minds

www.intechopen.com

\section{NOTIFICATION OF ACCEPTANCE}

August 21, 2012

Dear Professor Bessho,

On behalf of the Editorial Board it is my pleasure to inform you that the manuscript titled "Feasibility of gene therapy for tooth regeneration by stimulation of a third dentition" has been accepted for publication in the book "Gene Therapy / Book 2", ISBN 980-953-307-690-9.

We firmly believe that your contribution will be of great importance for the scientific community.

Sincerely yours,

Aleksandar Lazinica, CEO

trasizizat

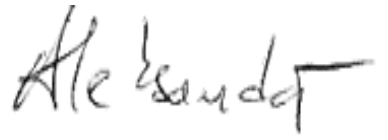

INTECH 


\section{Feasibility of gene therapy for tooth regeneration by stimulation of a third dentition}

Katsu Takahashi, Honoka Kiso, Kazuyuki Saito, Yumiko Togo, Hiroko Tsukamoto, Boyen Huang, and Kazuhisa Bessho

Department of Oral and Maxillofacial Surgery, Graduate School of Medicine, Kyoto University, 54, Kawahara-cho Shogoin, Sakyo-ku, Kyoto, 606-8507, Japan

\section{Introduction}

The tooth is a complex biological organ that consists of multiple tissues, including enamel, dentin, cementum, and pulp. Missing teeth is a common and frequently occurring problem in aging populations. To treat these defects, the current approach involves fixed or removable prostheses, autotransplantation, and dental implants. The exploration of new strategies for tooth replacement has become a hot topic. Using the foundations of experimental embryology, developmental and molecular biology, and the principles of biomimetics, tooth regeneration is becoming a realistic possibility. Several different methods have been proposed to achieve biological tooth replacement [1-8]. These include scaffold-based tooth regeneration, cell pellet engineering, chimeric tooth engineering, stimulation of the formation of a third dentition, and gene-manipulated tooth regeneration. The idea that a third dentition might be locally induced to replace missing teeth is an attractive concept $[5,8,9]$. This approach is generally presented in terms of adding molecules to induce de novo tooth initiation in the mouth. It might be combined with gene-manipulated tooth regeneration; that is, endogenous dental cells in situ can be activated or repressed by a gene-delivery technique to produce a tooth. Tooth development is the result of reciprocal and reiterative signaling between oral ectoderm-derived dental epithelium and cranial neural crest cell-derived dental mesenchyme under genetic control [10-12]. More than 200 genes are known to be expressed during tooth development (http://bite-it.helsinki.fi/). A number of mouse mutants are now starting to provide some insights into the mechanisms of supernumerary tooth formation. Multiple supernumerary teeth may have genetic components in their etiology and partially represent the third dentition in humans. Such candidate 
molecules or genes might be those that are involved in embryonic tooth induction, in successional tooth formation, or in the control of the number of teeth. This means that it may be possible to induce de novo tooth formation by the in situ repression or activation of a single candidate gene. In this review, we present an overview of the collective knowledge of tooth regeneration, especially regarding the control of the number of teeth for gene therapy by the stimulation of a third dentition.

\section{The third dentition}

It has been suggested that, in humans, a "third dentition" with one or more supernumerary teeth can occur in addition to the permanent dentition, and supernumerary teeth are sometimes thought to represent a partial post-permanent dentition [13-15]. The basic dentition pattern observed in mammals is diphyodont, and consists of three incisors, one canine, four premolars, and three molars, while Human teeth are diphyodont excepting the permanent molars [16]. The deciduous teeth are, ontogenetically, the first generation of teeth. The permanent teeth (except molar) belong to the second dentition. The term "third dentition" refers to the opinion that one more set of teeth can occur in addition to the permanent teeth (Figure 1). Human teeth are diphyodont excepting the permanent molars. The normal mouse dentition is monophyodont and composed of one incisor and three molars in each quadrant. The number of teeth is usually strictly determined. It was initially reported that there is an anlagen of the third dentition in some mammals [17]. The presence of an epithelial anlagen of the third dentition was also noticed in humans $[18,19]$. The teeth and anlagen that appear in third dentition in serial sections of infant jaws and some fetuses have been analyzed. The epithelium which is considered as the anlagen of the third dentition develops lingual to all permanent tooth germs [15]. Furthermore, when it appears, the predecessor (permanent tooth germ) is in the bell-shaped stage [15]. The timing of appearance of the third dentition seems to be after birth (Table 1). This means that we have a chance to access the formation of the third dentition in the mouth.

Analysis of other model systems with continuous tooth replacement or secondary tooth formation, such as in the fish, snake, lizard, and ferret, is providing insights into the molecular and cellular mechanisms underlying successional tooth development, and will assist in studies on supernumerary tooth formation in humans. While some nonmammalian species have multirowed dentition and replace their teeth regularly throughout life, mammalian vertebrates have one row of teeth and only 
renew their teeth once, or, in some rodents, show no replacement [20-23]. Detailed histological analysis of the tooth replacement in these models indicates that the successional teeth are initiated from the dental lamina epithelium, which grows from the lingual side of the deciduous tooth enamel organ, and it later elongates and buds into the jaw mesenchyme, forming successional teeth. Jarvien et al. showed that, in the ferret, Sostdc1 (also known as USAG-1, ectodin, and Wise) is expressed in the elongating successional dental lamina at the interface between the lamina and deciduous tooth, as well as the buccal side of the dental lamina, suggesting that Sostdc1 plays a role in defining the identity of the dental lamina [20]. Handrigan et al. analyzed successional tooth formation in the snake and in lizard, and proposed that dental epithelium stem cells are responsible for the formation of successional lamina, and Wnt signaling may regulate the stem cell fate in these cells [24]. Maintenance or reactivation of component dental lamina is thus pivotal for the replacement tooth and supernumerary formation.

\section{Human syndromes associated with supernumerary teeth}

Supernumerary teeth can be associated with a syndrome (Table 2) or they can be found in non-syndromic patients [25-28]. Only $1 \%$ of non-syndromic cases have multiple supernumerary teeth, which occur most frequently in the mandibular premolar area, followed by the molar and anterior regions, respectively [29-34]. There are special cases exhibiting permanent supernumerary teeth developing as supplementary teeth forming after the permanent teeth. These are thought to represent a third dentition, best known as manifestations of cleidocranial dysplasia (CCD).

Genetic mutations have been associated with the presence or absence of individual types of teeth. Supernumerary teeth are associated with more than 20 syndromes and developmental abnormalities like CCD, and Gardner syndrome [35]. The percentage occurrence in CCD is $22 \%$ in the maxillary incisor region and 5\% in the molar region [36-38]. CCD is a dominantly inherited skeletal dysplasia caused by mutations in RUNX2 [39-40]. It is characterized by persistently open sutures or the delayed closure of sutures, hypoplastic or aplastic clavicles, a short stature, delayed eruption of permanent dentition, supernumerary teeth, and other skeletal anomalies. There is a wide spectrum of phenotypic variability ranging from the full-blown phenotype to an isolated dental phenotype characterized by supernumerary tooth formation and/or the delayed eruption of permanent teeth in CCD (Figure 1) 
[41-44]. A dose-related effect seems to be present, as the milder case of CCD, and those exhibiting primary dental anomalies, are related to mutations that reduce, but do not abolish, protein stability, DNA binding, and transactivation [41,43-45]. Runx2-deficient mice were found to exhibit lingual buds in front of the upper molars, and these were much more prominent than in wild-type mice $[46,47]$. These buds presumably represent the mouse secondary dentition, and it is likely that RUNX2 acts to prevent the formation of these buds. RUNX2 usually functions as a cell growth inhibitor [43]. Runx 2 regulates the proliferation of cells and may exert specific control on the dental lamina and formation of successive dentitions. Runx 2 heterozygous mutant mice mostly phenocopied the skeletal defects of CCD in humans, but with no supernumerary tooth formation [48] (Otto, 1997). Notably, in Runx2 homozygous and heterozygous mouse upper molars, a prominent epithelial bud regularly presents. This epithelial bud protrudes lingually with active Shh signaling, and it may represent the extension of the dental lamina for successional tooth formation in mice. Hence, although Runx2 is required for primary tooth development, it prevents the growth of the dental lamina and successional tooth formation [47].

Familial adenomatous polyposis (FAP), also named adenomatous polyposis of the colon (APC), is an autosomal dominant hereditary disorder characterized by the development of many precancerous colorectal adenomatous polyps, some of which will inevitably develop into cancer. In addition to colorectal neoplasm, individuals can develop variable extracolonic lesions, including upper gastrointestinal polyposis, osteomas, congenital hypertrophy of the retinal pigment epithelium, soft tissue tumors, desmoid tumors, and dental anomalies [49-53]. Dental abnormalities include impacted teeth, congenital absence of one or more teeth, supernumerary teeth, dentigerous cysts associated with the crown of an unerupted tooth, and odontomas [50,52]. Gardner syndrome is a variant of FAP characterized by multiple adenomas of the colon and rectum typical of FAP together with osteomas and soft tissue tumors[49,51]. Supernumerary teeth and osteomas were originally described as a part of Gardner syndrome, but they can also occur in FAP patients with or without other extracolonic lesions [51,52]. FAP and Gardner syndrome are caused by a large number of germinal mutations in the $A P C$ gene [52,53]. $A P C$ is a tumor suppressor gene involved in the down-regulation of free intracellular ß-catenin, the major signal transducer of the canonical Wnt signaling pathway, as well as a central component of the E-cadherin adhesion complex [54,55]. In addition, the $A P C$ protein may 
also play roles in chromosomal stability, the regulation of cell migration up the colonic crypt and cell adhesion through association with GSK3ß, and other functions associated with microtubule bundles [55,56]. Inactivation of $A P C$ would lead to the stabilization and accumulation of the proto-oncogene B-catenin, disregulation of the cell cycle, and chromosomal instability [52]. Approximately $11-27 \%$ of patients have supernumerary teeth, but, so far, no specific codon mutation of the $A P C$ gene has been found to correlate with supernumerary teeth. Correlations seems to exist between dental abnormalities and the number and type of osteomas, with the highest incidence of supernumerary teeth and odontomas being found in FAP patients with three or more osteomas [52]. Conditional knockout of the Apc-gene resulted in supernumerary teeth in mice [57-59] . Notably, adult oral tissues, especially young adult tissues, are still responsive to the loss of Apc [60]. In old adult mice, supernumerary teeth can be induced on both labial and lingual sides of the incisors, which contain adult stem cells supporting the continuous growth of mouse incisors [60,61]. In young mice, supernumerary tooth germs were induced in multiple regions of the jaw in both incisor and molar regions. They can form directly from the oral epithelium, in the dental lamina connecting the developing molar or incisor tooth germ to the oral epithelium, in the crown region, as well as in the elongating and furcation area of the developing root [60].

The identification of mutations in $R U N X 2$ causing an isolated dental phenotype in CCD and in APC causing FAP has attracted attention as a possible route towards inducing de novo tooth formation.

\section{Supernumerary tooth formation in a mouse model}

The number of teeth is usually strictly determined. Whereas evidence supporting a genetic etiology for tooth agenesis is well established, the etiology of supernumerary tooth formation is only partially understood in the mouse model (Table 3). Unlike humans, mice have only molars and incisors separated by a toothless region called the diastema. In addition, mice only have a single primary dentition and their teeth are not replaced. Therefore, mice may not be an optimal model for studying tooth replacement and supernumerary tooth formation [62]. Most of the reported mouse supernumerary teeth are located in the diastema region. This is not a de novo tooth formation but the rescue of vestigial tooth rudiments. During the early stages of tooth development, many transient 
vestigial dental buds develop in the diastema area. Some of them can develop into the bud stage, but later regress and disappear by apoptosis, or merge with the mesial crown of the first molar tooth[63-68]. Major signaling pathways regulating tooth development are also expressed in these vestigial dental buds. Modulation of these signals can rescue these vestigial tooth rudiments to develop into supernumerary diastema teeth [23]. A number of mutant mouse strains have been reported exhibiting supernumerary diastema teeth. Although the rudimentary tooth buds form in the embryonic diastema, they regress apoptically [69]. Transgenic mice in which the keratin 14 promoter directs Ectodysplasin (Eda), a member of the tumor necrosis factor (TNF) family of signaling molecules, or Eda receptor expression to the epithelium had supernumerary teeth mesial to the first molar as a result of diastema tooth development [70-72]. It has also been reported that Sprouty2 (Spry2) or Spry4 (which encode negative feedback regulators of fibroblast growth factor (FGF)) deficient mice showed supernumerary tooth formation as a result of diastema tooth development [73]. Hypomorphic Polaris mice and Wnt-Cre (Polaris conditional mutant mice with affected Shh signaling) [73-74], Pax6 mutant mice [75] and Gas1 null mutants [73] were also included. Uterine sensitization associated gene-1 (USAG-1) is a BMP antagonist, and also modulates Wnt signaling. We reported that USAG-1-deficient mice have supernumerary teeth (Figure 2).

The supernumerary maxillary incisor appears to form as a result of the successive development of the rudimentary upper incisor. USAG-1 abrogation rescued apoptotic elimination of odontogenic mesenchymal cells [14]. BMP signaling in the rudimentary maxillary incisor, assessed by expressions of Msx1 and Dlx2 and the phosphorylation of Smad protein, was significantly enhanced. Wnt signaling, as demonstrated by the nuclear localization of $\beta$-catenin, was also up-regulated. The inhibition of BMP signaling rescues supernumerary tooth formation in E15 incisor explant culture. Based upon these results, we conclude that enhanced BMP signaling results in supernumerary teeth and BMP signaling was modulated by Wnt signaling in the USAG-1-deficient mouse model (Figure 3) [76]. Canonical Wnt/ $\beta$-catenin signaling and its down-stream molecule Lef-1 are essential for tooth development [77].

Overexpression of Lef-1 under the control of the K14 promoter in transgenic mice leads to the development abnormal invaginations of the dental epithelium in the mesenchyme and formation of a tooth-like structure [78]. De novo supernumerary teeth arising directly from the primary tooth germ or 
dental lamima have been reported in Apc loss-of-function (as discussed in the previous section) or $\beta$-catenin gain-of-function mice, and Sp6 (Epiprofin)-deficient mice. It was demonstrated that mouse tooth buds expressing stabilized $\beta$-catenin give rise to extra teeth [58] (Jarvinen et al., 2006). More recently, Epiprofin (Epfn) (a zinc finger transcription factor belonging to the Sp transcription factor superfamily)-deficient mice developed an excess number of teeth [79]. Mammals only have one row of teeth in each jaw. Interestingly, in the $O s r 2$ null mutant mouse embryo, supernumerary tooth germs were found developing directly from the oral epithelium lingual to their molar tooth germs [80]. More recently, we also demonstrated that CEBPB deficiency was related to the formation of supernumerary teeth [81]. A total of $66.7 \%$ of $\mathrm{CEBPB}^{-/-} 12$-month-olds sustained supernumerary teeth and/or odontomas in the diastema between the incisor and the first molar. Two supernumerary teeth accompanied with an a10 complex odontoma near the root of the upper right incisor were identified in

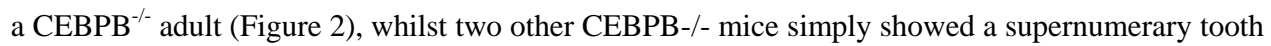
in the upper left quadrant. Another $\mathrm{CEBPB}^{-{ }^{-}}$adult mouse did not display any supernumerary teeth in either jaw, but an odontoma in the lower-right quadrant. All of the $\mathrm{CEBPB}^{-/-}$adults appeared with a normal number of erupted incisors and molars. Nevertheless, $20 \%$ of the $\mathrm{CEBPB}^{+/}$12-month-olds had a missing lower third molar. Dental anomalies such as supernumerary teeth, odontomas, or hypodontia were not found in mice of any other genotypes and/or age [81].

These mouse models clearly demonstrated that it was possible to induce de novo tooth formation by the in situ repression or activation of single candidate gene such as USAG-1.

\section{Gene therapy approaches}

Gene therapy provides a unique tool for the delivery of previously identified signaling molecules in both time and space that may significantly augment our progress toward clinical tooth regeneration. Stimulation of the formation of a third dentition and gene-manipulated tooth regeneration comprise an attractive concept (Figure 4). This approach is generally presented in terms of adding molecules to induce de novo tooth initiation in the mouth. It might be combined with gene-manipulated tooth regeneration; that is, endogenous dental cells in situ can be activated or repressed by a gene-delivery technique to make a tooth. We have a chance to access the formation of the third dentition in the mouth, because the time of appearance of the third dentition seems to be after birth. As the half-life of 
targeted proteins in vivo is transient, tooth regeneration is not a common outcome following conventional therapy. Typically, high concentrations are required to promote regeneration [82]). Therefore, supplemental local production via gene transfer could be superior to bolus delivery methods.

Simply stated, gene therapy consists of the insertion of genes into an individual's cells directly or indirectly with a matrix to promote a specific biological effect. Gene therapy can be used to induce a more favorable host response. Targeting cells for gene therapy requires the use of vectors or direct delivery methods to transfect them. To overcome the short half-lives of peptides in vivo, gene therapy that uses a vector that encodes the candidate genes is utilized to stimulate the formation of the third dentition. The two main strategies of gene vector delivery have been applied. Gene vectors can be introduced directly to the target site (in vivo gene delivery) [83] or selected cells can be harvested, expanded, genetically transduced, and then reimplanted (ex vivo gene delivery). In vivo gene transfer involves the insertion of the gene of interest directly into the body, anticipating the genetic modification of the target cells. Ex vivo gene transfer includes the incorporation of genetic material into cells exposed from a tissue biopsy with subsequent reimplantation into the recipient. So far, in vivo gene delivery has been a suitable gene therapy approach in tooth regeneration by stimulation of the third dentition, but ex vivo gene delivery is not realistic because of the poor availability of ideal cells.

Gene transfer is accomplished through the use of viral and nonviral vectors. The three main classes of virus used for gene therapy are the retrovirus, adenovirus, and adenoassociated viruses. Retroviruses are ideal for long-term gene therapy since, once introduced, their DNA integrates and becomes part of the genome of the host cells. Indeed, the current human genome contains up to 5 to $8 \%$ of endogenous retroviral sequences that have been acquired over the course of evolution [84]. Adenoviruses are more commonly suited for short-term gene delivery and are highly targeted for tissue engineering strategies that desire protein production over the course of several weeks. Efficient adenovirus-directed gene delivery to odontogenic ectomsenchymal cells derived from cranial neural crest cells was reported $[85,86]$. In addition, because the adenovirus is well-known as the "virus of the common cold," infection is generally nontoxic and self-limiting. However, determination of the genotoxicity for each specific application is necessary to keep the safety profile within acceptable parameters. 
Adenoassociated viruses have become the focus of much research in recent years because of their complete inability to replicate without a helper virus, potential for tissue-specific targeting, and gene expression in the order of months to years. The ability to specifically target one tissue type without adverse effects on neighboring tissues is highly desired in fields such as tooth regeneration. On the other hand, nonviral methods are safe and do not require immunosuppression for successful gene delivery, but suffer from lower transfection efficiencies. DNA injection followed by application of electric fields (electroporation) has been more effective for introducing DNA than the use of simple DNA injection [87]. However, this method involves the concern that the electric pulse causes tissue damage. Recently, we reported that gene transfer using an ultra-fine needle [88], in addition to microbubbles enhanced transcutaneous sonoporation [87]. In vivo gene delivery seems to be a suitable gene therapy approach in tooth regeneration by stimulation of the third dentition.

\section{Conclusion}

We have a chance to access the formation of the third dentition in the mouth, because the timing of the appearance of the third dentition seems to be after birth. The identification of mutations in $R U N X 2$ causing an isolated dental phenotype in CCD and supernumerary tooth formation in the mouse model clearly demonstrated that it was possible to induce de novo tooth formation by the in situ repression or activation of a single candidate gene. These results support the idea that the de novo repression or activation of candidate genes such as RUNX2 or USAG-1 might be used to stimulate the third dentition in order to induce new tooth formation in the mouse (Figure 4). In vivo gene delivery seems to be a suitable gene therapy approach in tooth regeneration by stimulation of the third dentition.

\section{Acknowledgement}

This work was supported by Grant-in-Aid for Scientific Research(C):22592213 and Grant-in-Aid for JSPS Fellows:02109741. 


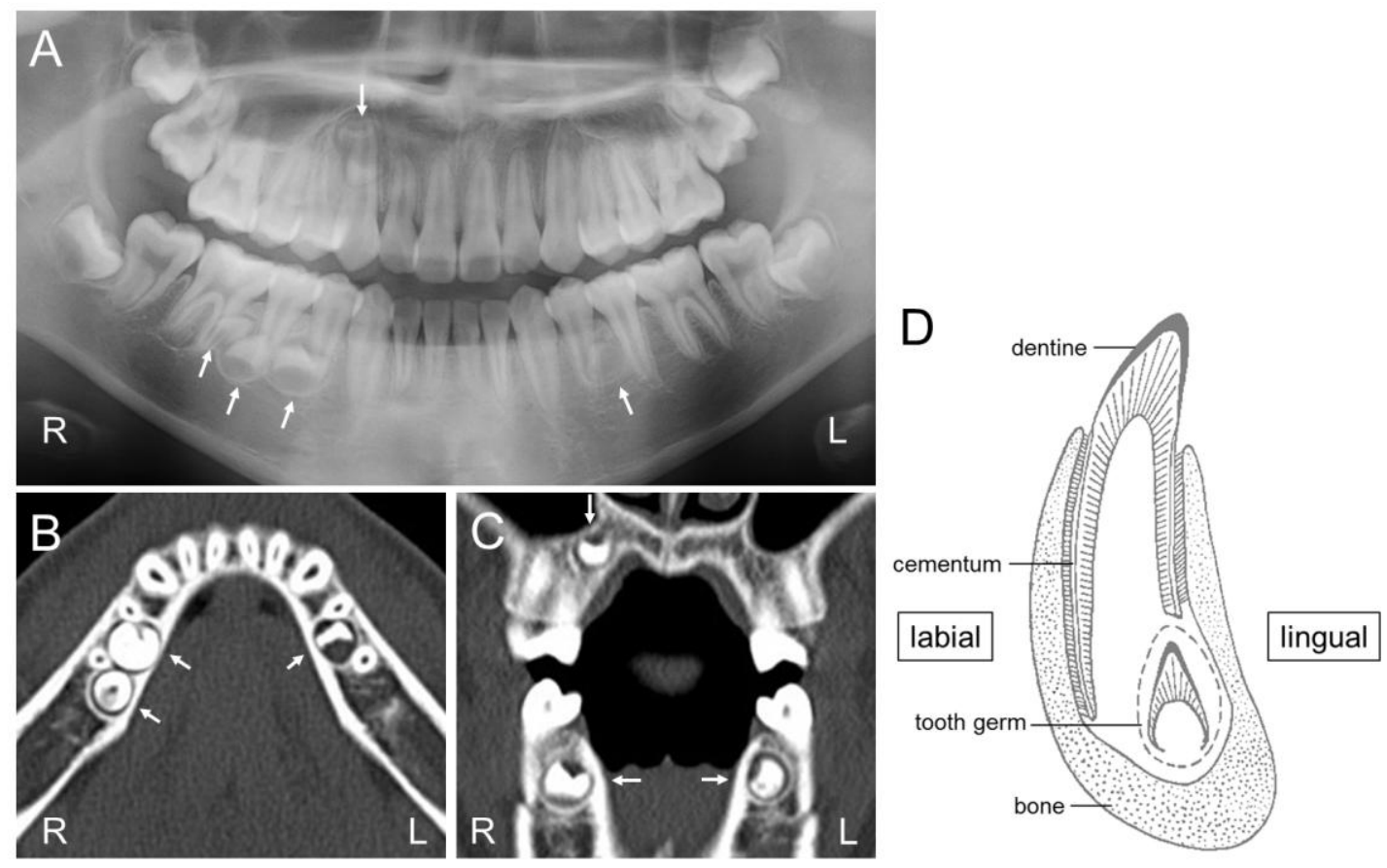

Figure 1. Multiple impacted supernumerary teeth in a 13-year-old non-syndromic patient. The third dentition develops lingual to the permanent tooth germ (D). All impacted supernumerary teeth in this patient are located to the lingual side of the permanent teeth (white arrow) (A-C). These multiple supernumerary teeth seem to be post-permanent dentition ("third dentition").

Table 1 Timing of appearance of the third dentition

\begin{tabular}{|l|l|l}
\hline \multirow{2}{*}{ Teeth } & \multicolumn{2}{|l}{ The time of appearance of the third dentition } \\
\cline { 2 - 3 } & Maxilla & Mandible \\
\hline central incisors & $\sim 3$ months after birth & $2 \sim 3$ months after birth \\
lateral incisors & $8 \sim 9$ months after birth & $2 \sim 3$ months after birth \\
canines & $2 \sim 7$ months after birth \\
the first premolar & 1 year 1 month $\sim 5$ years 4 months after birth \\
the second premolar & 1 year 1 month $\sim 5$ years 4 months after birth & $2 \sim 3$ months after birth \\
\end{tabular}


Table 2 Human syndromes associated with supernumerary teeth

\begin{tabular}{|c|c|c|c|}
\hline Syndrome & Gene & Genetics & References \\
\hline $\begin{array}{l}\text { Cleidocranial Dysplasia; CCD } \\
\text { (Dental anomalies, isolated dental phenotype) (MIM 119600) }\end{array}$ & $\begin{array}{l}\text { Runx2 } \\
\text { (MIM 600211) }\end{array}$ & $\begin{array}{l}\text { Chromosome } 6 \mathrm{p} 21 \text {, } \\
\text { autosomal dominant }\end{array}$ & Lee et al., 1997; Mundlos et al., 1997. \\
\hline $\begin{array}{l}\text { Familial adenomatous polyposis 1; FAP1 } \\
\text { (including Gardner syndrome) (MIM 175100) }\end{array}$ & $\begin{array}{l}\text { APC } \\
(\text { MIM 611731) }\end{array}$ & $\begin{array}{l}\text { Chromosome } 5 q 21-22 \text {, } \\
\text { autosomal dominant }\end{array}$ & $\begin{array}{l}\text { Fader et al., 1962; Ida et al., 1981; } \\
\text { Shafer et al.,1983; Jensen and Kreiborg, } 1990 .\end{array}$ \\
\hline $\begin{array}{l}\text { Nance-Horan syndrome } \\
\text { (Cataract-Dental syndrome) (MIM 302350) }\end{array}$ & $\begin{array}{l}\text { NHS } \\
\text { (MIM 300457) }\end{array}$ & $\begin{array}{l}\text { Chromosome Xp22.13, } \\
\text { X-linked dominant }\end{array}$ & $\begin{array}{l}\text { Bixler et al., 1984; Van Dorp and Delleman, } \\
\text { 1979; Walpole et al., 1990; Burdon et al., } 2003 .\end{array}$ \\
\hline $\begin{array}{l}\text { Trichorhinophalangeal syndrome, Type III (TRPS3) } \\
\text { (MIM 190351) }\end{array}$ & $\begin{array}{l}\text { TRPS1 } \\
(\text { MIM 604386) }\end{array}$ & $\begin{array}{l}\text { Chromosome } 8 \mathrm{q} 23.3 \text {, } \\
\text { autosomal dominant }\end{array}$ & $\begin{array}{l}\text { Giedion., 1966; Momeni et al., 2000; } \\
\text { Kantaputra et al., } 2008 .\end{array}$ \\
\hline Robinow syndrome (MIM 180700) & $\begin{array}{l}\text { WNT5A } \\
\text { (MIM 164975) }\end{array}$ & $\begin{array}{l}\text { Chromosome } 3 p 14.3 \\
\text { autosomal dominant }\end{array}$ & Mazzeu et al., 2007. \\
\hline Hallermann-Streiff syndrome; HSS (MIM 234100) & $\begin{array}{l}\text { GJA1 } \\
(\text { MIM 121014) }\end{array}$ & $\begin{array}{l}\text { Chromosome } 6 \mathrm{q} 22.31 \\
\text { Isolated cases }\end{array}$ & $\begin{array}{l}\text { da Fonseca and Mueller, 1994; Robotta and } \\
\text { Schafer, } 2011 .\end{array}$ \\
\hline Rothmund-Thomson Syndrome; RTS (MIM 268400) & $\begin{array}{l}\text { RECQL4 } \\
(\text { MIM 603780) }\end{array}$ & $\begin{array}{l}\text { Chromosome } 8 \mathrm{q} 24.3 \text {, } \\
\text { autosomal recessive }\end{array}$ & Kitao et al., 1999. \\
\hline $\begin{array}{l}\text { Orofaciodigital Syndrome I; OFD1 } \\
\text { (Papillon-Leage and Psaume syndrome) (MIM 311200) }\end{array}$ & $\begin{array}{l}\text { OFD1 } \\
\text { (MIM 300170) }\end{array}$ & $\begin{array}{l}\text { Chromosome Xp22.2, } \\
\text { X-linked dominant }\end{array}$ & Ferrante et al., 2001. \\
\hline $\begin{array}{l}\text { Uncombable Hair,Retinal Pigmentary Dystrophy, Dental } \\
\text { Anomalies,and Brachydactyly (Bork Syndrome) (MIM 191482) }\end{array}$ & Unknown & autosomal dominant & Silengo et al., 1993. \\
\hline
\end{tabular}


Table 3 Mutant mouse associated with supernumerary teeth

\begin{tabular}{|c|c|c|}
\hline Mutant mouse & Tooth phenotype & references \\
\hline $\begin{array}{l}\text { Sostdc1-/- } \\
\text { (USAG-1, ectodin, Wise) }\end{array}$ & $\begin{array}{l}\text { Supernumerary incisors in the maxilla and mandible } \\
\text { Premolar mesial to first molar, peg-shaped tooth lingual to first molar }\end{array}$ & $\begin{array}{l}\text { Munne et al., 2009; } \\
\text { Ohazama et al., 2008; } \\
\text { Yanagita et al., 2006; } \\
\text { Murashima-Suginami et al., } \\
2007,2008 .\end{array}$ \\
\hline CEBPB-/- & $\begin{array}{l}\text { Supernumerary teeth and/or odontomas in the diastema between the incisor and } \\
\text { the first molar }\end{array}$ & Huang et al., 2012. \\
\hline Gas1-1- & Premolar mesial to first molar, both jaws ( $100 \%$ penetrance) & Ohazama et al., 2009. \\
\hline Gas1-/-; Shh+/- & Mandibular molar (associated with jaw duplication) & Seppala et al., 2007. \\
\hline Tg737orpk hypomorph & Premolar mesial to first molar, both jaws ( $100 \%$ penetrance) & $\begin{array}{l}\text { Zhang et al., 2003; Ohazama } \\
\text { et al., 2009,. }\end{array}$ \\
\hline Wnt1-Cre; Polaris flox/flox & Premolar mesial to first molar, both jaws ( $100 \%$ penetrance) & Ohazama et al., 2009. \\
\hline Spry2-/- & $\begin{array}{l}\text { Premolar mesial to first molar; maxilla ( }>5 \%) \text {, mandible ( } 97 \% \text { : } 92 \% \text { bilateral; } 5 \% \\
\text { unilateral) }\end{array}$ & $\begin{array}{l}\text { Klein et al., 2006; Peterkovaet } \\
\text { al., } 2009 .\end{array}$ \\
\hline Spry4-/- & Both jaws? $16 \%$ penetrance (most unilateral) & Klein et al., 2006. \\
\hline Lrp4-/- (Megf7) hypomorph & $\begin{array}{l}\text { Supernumerary incisors in the maxilla and mandible } \\
\text { Premolar mesial to first molar (varying penetrance in both jaws) } \\
\text { Lingual peg-shaped tooth (maxilla, variable penetrance) }\end{array}$ & Ohazama et al., 2008. \\
\hline Osr2-1- & Lingual molars & Zhang et al., 2009. \\
\hline Epiprofin-/- & Multiple incisors and molars in both jaws & Nakamura et al., 2008. \\
\hline K14-Cre; Apc ${ }^{\text {cko/cko }}$ & Multiple incisor and molar tooth buds & Kuraguchi et al., 2006. \\
\hline $\mathrm{K} 14-\mathrm{Cre}{ }^{8 \mathrm{Brn}} ; \mathrm{Apc} \mathrm{cko/cko}^{\mathrm{k}}$ & Numerous labial and lingual incisor and molar teeth ( $\uparrow$ with age) & Wang et al., 2009. \\
\hline K14-Cre ${ }^{1 \mathrm{Amc}} ; \mathrm{Apc}^{\mathrm{cko} / \mathrm{cko}}$ & Numerous epithelial buds from E14.5 & Wang et al., 2009. \\
\hline K14-CreER ${ }^{\mathrm{TM}} ; \mathrm{Apc}^{\mathrm{cko} / \mathrm{cko}}$ & Numerous labial and lingual incisors (age P5-10/12) & Wang et al., 2009. \\
\hline K14-CreER ${ }^{\mathrm{TM}} ; \mathrm{Ctnb} 1^{(\mathrm{e} \times 3) / f 1+}$ & $\begin{array}{l}\text { Numerous labial and lingual incisors (age P5-6/12) } \\
\text { P5 molar supernumeraries }\end{array}$ & Wang et al., 2009. \\
\hline K14-Cre/+; $\beta$-cateninex3fl/+ & Multiple incisor and molar epithelial invaginations in both jaws & Jarvinen et.al., 2006. \\
\hline K14-Cre; Ctnnb1(ex3)fl/+ & Multiple molar epithelial invaginations & Liu et al., 2008. \\
\hline K14-Lef1 & Rudimentary teeth at inappropriate sites & Zhou et. Al., 1995. \\
\hline Pax6 Sey & Incisor supernumeraries: $35 \%$ unilateral; $45 \%$ bilateral incisors & Kaufman et al., 1995. \\
\hline K14-Eda & Premolar mesial to first molar; incomplete penetrance & $\begin{array}{l}\text { Kangas et al., } 2004 \\
\text { Mustonen et al., } 2003 .\end{array}$ \\
\hline K14-Edar & Premolar mesial to first molar; incomplete penetrance & Tucker et al., 2004. \\
\hline Tabby+/- & Molar $(2.5 \%$; mandible $>$ maxilla $)$ & $\begin{array}{l}\text { Gruneberg et al., 1966; } \\
\text { Sofaer et al., } 1969 .\end{array}$ \\
\hline B6CBACa-Aw-J/A-EdaTa/0 & Molar $(1 \%$; mandible >maxilla) & Peterkova et al., 2005. \\
\hline di & Mandibular incisors (right $>$ left) & Danforth et al., 1958. \\
\hline$\beta$-cat ${ }^{\Delta e \times 3 K 14 /+}$ & Supernumerary molars in the maxilla and mandible & Järvinen, E., 2006 \\
\hline
\end{tabular}



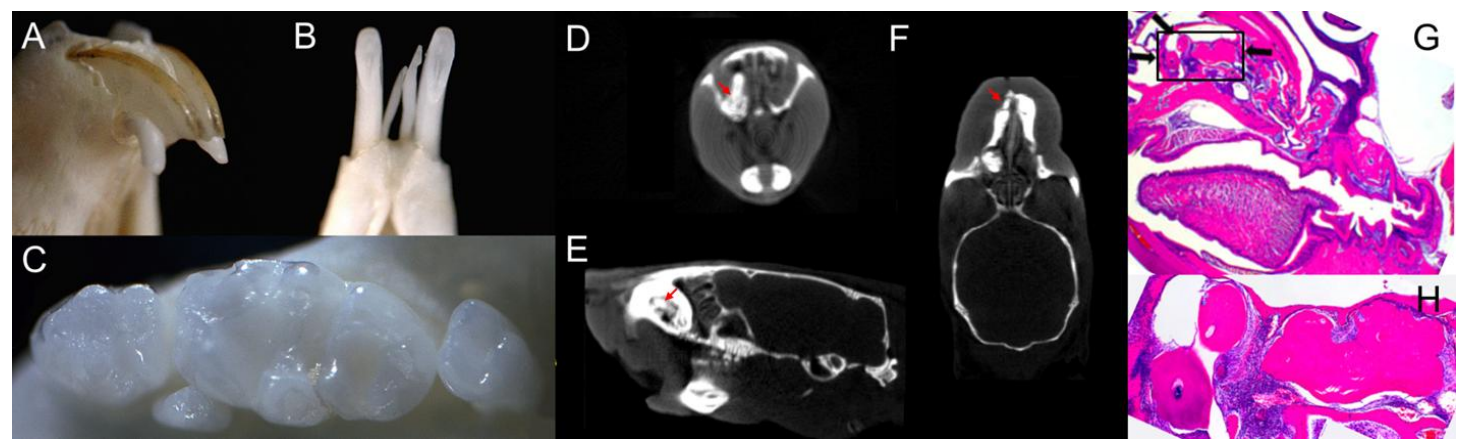

Figure 2. Supernumerary teeth formation in Sostdc 1 (USAG-1) (A-C) and CEBPB (D-H) adult mutant mice. A: Oblique view of the maxillary incisors. B: Occlusal view of the mandibular incisors. C: Occlusal view of the mandibular molars. Micro-CT images (D-F) and HE-staining (G,H) of the murine head. A frontal view (D), a sagittal view (E) and a horizontal view (F) showed supernumerary tooth (red arrow). Two supernumerary teeth and a odontoma were seen in a low $(\mathrm{G})$ and a high $(\mathrm{H})$ magnification. 


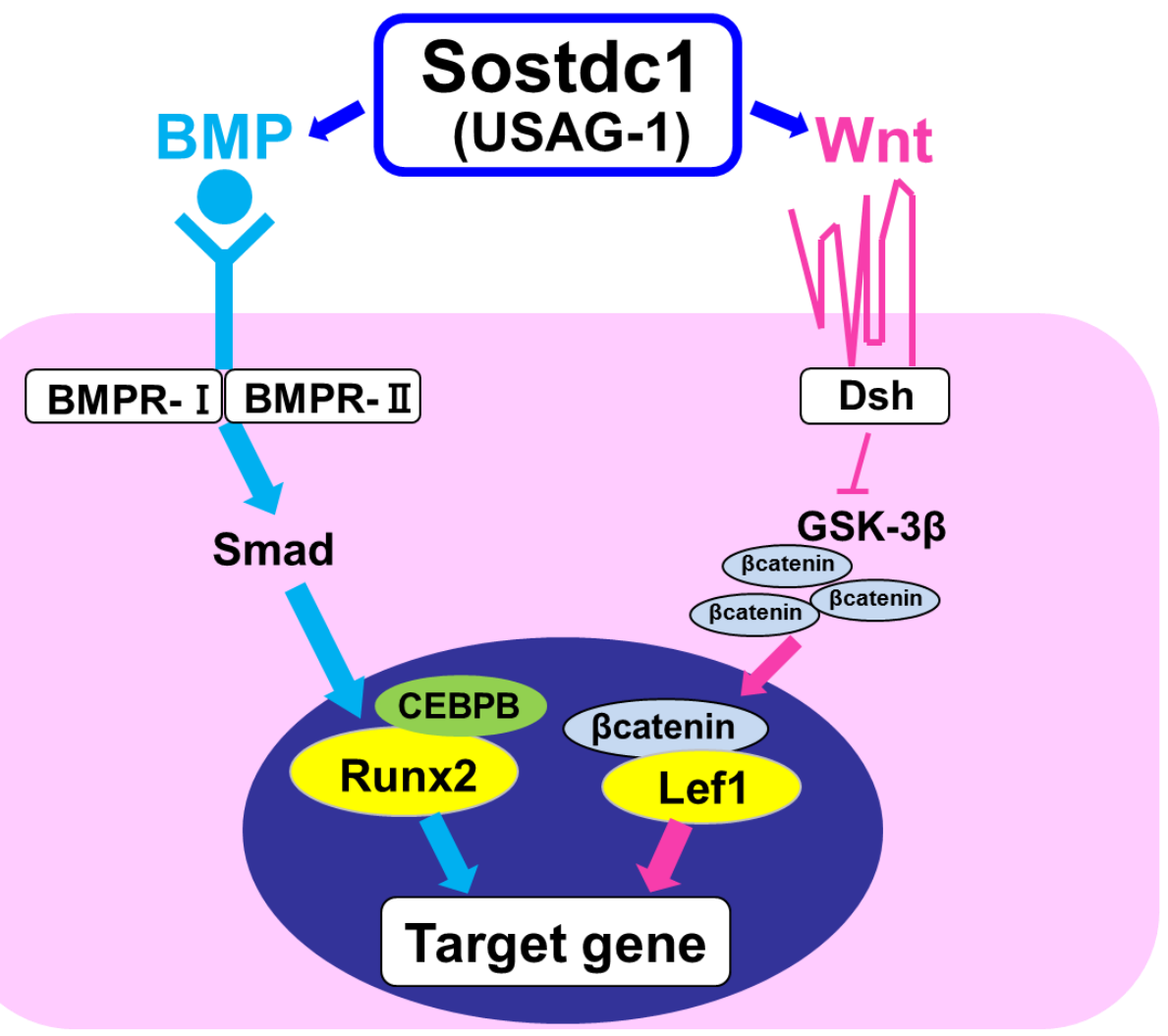

Figure 3. Diagrammatic representation of the Sostdc1 (USAG-1) pathway during tooth development 


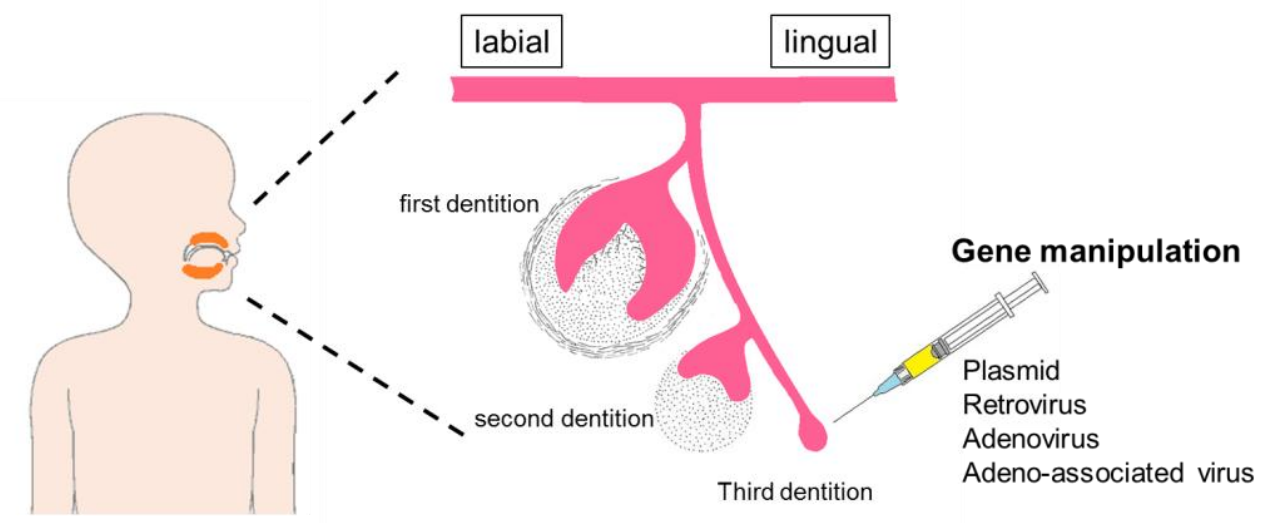

Figure 4. In vivo gene delivery approach for the tooth regeneration by stimulation of a third dentition.

\section{References}

[1] Ohazama A, Modino SA, Miletich I, Sharpe PT. Stem-cell-based tissue engineering of murine teeth. J Dent Res 2004;83(7):518-522.

[2] Duailibi MT, Duailibi SE, Young CS, Bartlett JD, Vacanti JP, Yelick PC. Bioengineered teeth from cultured rat tooth bud cells. J Dent Res 2004;83(7):523-528.

[3] Young CS, Abukawa H, Asrican R, Ravens M, Troulis MJ, Kaban LB, Vacanti JP, Yelick PC. Tissue-engineered hybrid tooth and bone. Tissue Eng 2005;11(9-10):1599-1610.

[4] Edwards PC, Mason JM. Gene-enhanced tissue engineering for dental hard tissue regeneration:

(1) overview and practical considerations. Head Face Med 2006;2:12.

[5] Sartaj R, Sharpe P. Biological tooth replacement. J Anat 2006;209(4):503-509.

[6] Nakao K, Morita R, Saji Y, Ishida K, Tomita Y, Ogawa M, Saitoh M, Tomooka Y, Tsuji T. The development of a bioengineered organ germ method. Nat Methods. 2007;4(3):227-230.

[7] Ferreira CF, Magini RS, Sharpe PT. Biological tooth replacement and repair. J Oral Rehabil 2007;34(12):933-939. 
[8] Yu J, Shi J, Jin Y. Current Approaches and Challenges in Making a Bio-Tooth. Tissue Eng Part B Rev 2008;14(3):307-319.

[9] Takahashi, K., Sakata, T., Murashima-Suginami, A., Tsukamoto, H., Kiso, H. and Bessho, K. Tooth regeneration: Potential for stimulation of the formation of a third dentition by one gene. Current Topics in Genetics 2008;3: 77-82.

[10] Thesleff I, Sharpe P. Signalling networks regulating dental development. Mech Dev 1997;67(2):111-123.

[11] Chai Y, Slavkin HC. Prospects for tooth regeneration in the 21st century: a perspective. Microsc Res Tech 2003;60(5):469-479.

[12] Thesleff I. The genetic basis of tooth development and dental defects. Am J Med Genet A 2006;140(23):2530-2535.

[13] Jensen BL, Kreiborg S. Development of the dentition in cleidocranial dysplasia. J Oral Pathol Med 1990;19(2):89-93.

[14] Murashima-Suginami A, Takahashi K, Kawabata T, Sakata T, Tsukamoto H, Sugai M, Yanagita M, Shimizu A, Sakurai T, Slavkin HC, Bessho K. Rudiment incisors survive and erupt as supernumerary teeth as a result of USAG-1 abrogation. Biochem. Biophys. Res. Commun 2007;359(3):549-555.

[15] Ooë T. Epithelial anlagen of human third dentition and their migrations in the mandible and maxilla. Okajimas Fol Anat Jap 1969; 46(5):243-251.

[16] Hillson S. Teeth. Cambridge:Cambridge University Press; 1986.

[17]Leche W. Studien uber die Entwicklung des Zahnsstemsbei den Saugetieren. Morph Jb 1893;19: 502-574.

[18] Rose C. Ubereste einer vorzeitigen pralaktealen und einer vierten Zahnreihe beim Menschen. Oester-ungar Viertjschr Zhik 1895;11:45-50.

[19] Ahrens H. Entwicklung der menschlichen Zahne. Anat Hefte 1913;48:169-267

[20]Järvinen E, Tummers M, Thesleff I. The role of the dental lamina in mammalian tooth replacement. J Exp Zool B Mol Dev Evol 2009 ;312B(4):281-291.

[21] Koussoulakou DS, Margaritis LH, Koussoulakos SL. A curriculum vitae of teeth: evolution, generation, regeneration. Int J Biol Sci 2009;5(3):226-243. 
[22] Mikkola ML. Controlling the number of tooth rows. Sci Signal 2009;2(85):pe53.

[23] Tummers M, Thesleff I. The importance of signal pathway modulation in all aspects of tooth development. J Exp Zool B Mol Dev Evol 2009;312B(4):309-319

[24] Handrigan GR, Leung KJ, Richman JM. Identification of putative dental epithelial stem cells in a lizard with life-long tooth replacement. Development 2010;137(21):3545-3549.

[25] Garvey MT, Barry HJ, Blake M. Supernumerary teeth--an overview of classification, diagnosis and management. J Can Dent Assoc 1999;65(11):612-616

[26] Liu DG, Zhang WL, Zhang ZY, Wu YT, Ma XC. Three-dimensional evaluations of supernumerary teeth using cone-beam computed tomography for 487 cases. Oral Surg Oral Med Oral Pathol Oral Radiol Endod 2007;103(3):403-11.

[27] Díaz A, Orozco J, Fonseca M. Multiple hyperodontia: report of a case with 17 supernumerary teeth with non syndromic association. Med Oral Patol Oral Cir Bucal 2009;14(5):E229-31.

[28] Ferrés-Padró E, Prats-Armengol J, Ferrés-Amat E. A descriptive study of 113 unerupted supernumerary teeth in 79 pediatric patients in Barcelona. Med Oral Patol Oral Cir Bucal 2009;14(3):E146-52

[29] Yusof WZ. Non-syndrome multiple supernumerary teeth: literature review. J Can Dent Assoc 1990;56(2):147-149.

[30] Batra P, Duggal R, Parkash H. Non-syndromic multiple supernumerary teeth transmitted as an autosomal dominant trait. J Oral Pathol Med 2005;34(10):621-625.

[31] Orhan AI, Ozer L, Orhan K. Familial occurrence of nonsyndromal multiple supernumerary teeth. A rare condition. Angle Orthod 2006;76(5):891-897.

[32] Hyun HK, Lee SJ, Ahn BD, Lee ZH, Heo MS, Seo BM, Kim JW. Nonsyndromic multiple mandibular supernumerary premolars. J Oral Maxillofac Surg 2008;66(7):1366-1369.

[33] Yagüe-García J, Berini-Aytés L, Gay-Escoda C. Multiple supernumerary teeth not associated with complex syndromes: a retrospective study._Med Oral Patol Oral Cir Bucal 2009;14(7):E331-336 [34] Inchingolo F, Tatullo M, Abenavoli FM, Marrelli M, Inchingolo AD, Gentile M, Inchingolo AM, Dipalma G. Non-syndromic multiple supernumerary teeth in a family unit with a normal karyotype: case report._Int J Med Sci 2010;7(6):378-384.

[35] Zhu JF, Marcushamer M, King DL, Henry RJ. Supernumerary and congenitally absent teeth: a 
literature review. J Clin Pediatr Dent 1996;20(2):87-95.

[36] Ida, M., Nakamura, T., and Utsunomiya, J. Osteomatous changes and tooth abnormalities found in the jaw of patients with adenomatosis coli. Oral Surg. Oral Med. Oral Pathol 1981;52(1), 2-11.

[37] Shafer, W. G., Hine, M. K., and Levi, B. M. Textbook of oral pathology $4^{\text {th }}$ Ed. Philadelphia:WB Saunders Co;1983.

[38] Jensen, B. L., and Kreiborg, S. Craniofacial growth in cleidocranial dysplasia--a roentgencephalometric study. J Craniofac Genet Deve Biol 1995;15(1): 35-43.

[39] Lee B, Thirunavukkarasu K, Zhou L, Pastore L, Baldini A, Hecht J, Geoffroy V, Ducy P, Karsenty G. Misense mutations abolishing DNA binding of the osteoblast-specific transcription factor OSF2/CBFA1 in cleidocranial dysplasia, Nature Genetics 1997 ;16(3): 307-310.

[40] Mundlos S, Otto F, Mundlos C, Mulliken JB, Aylsworth AS, Albright S, Lindhout D, Cole WG, Henn W, Knoll JH, Owen MJ, Mertelsmann R, Zabel BU, Olsen BR. Mutations involving the transcription factor CBFA1 cause cleidocranial dysplasia. Cell 1997; 89(5): 773-779.

[41] Zhou G, Chen Y, Zhou L, Thirunavukkarasu K, Hecht J, Chitayat D, Gelb BD, Pirinen S, Berry SA, Greenberg CR, Karsenty G, Lee B. CBFA1 mutation analysis and functional correlation with phenotypic variability in cleidocranial dysplasia, Hum Mol Genet 1999; 8(12): 2311-2316.

[42] Quack I, Vonderstrass B, Stock M, Aylsworth AS, Becker A, Brueton L, Lee PJ, Majewski F, Mulliken JB, Suri M, Zenker M, Mundlos S, Otto F. Mutation analysis of core biding factor A1 in patients with cleidocranial dysplasia. Am J hum Genet 1999; 65(5): 1268-1278.

[43] Yoshida T, Kanegane H, Osato M, Yanagida M, Miyawaki T, Ito Y, Shigesada K. Functional analysis of RUNX2 mutations in Japanese patients with cleidocranial dysplasia demonstrates novel genotype-phenotype correlations. Am J Hum Genet 2002;71(4):724-738.

[44] Baumert U, Golan I, Redlich M, Aknin JJ, Muessig D. Cleidocranial dysplasia: molecular genetic analysis and phenotypic-based description of a Middle European patient group. Am J Med Genet A 2005;139A(2):78-85.

[45] Yoshida T, Kanegane H, Osato M, Yanagida M, Miyawaki T, Ito Y, Shigesada K. Functional analysis of RUNX2 mutations in cleidocranial dysplasia: novel insights into genotype-phenotype correlations. Blood Cells Mol Dis 2003;30(2):184-193. 
[46] Aberg T, Cavender A, Gaikwad JS, Bronckers AL, Wang X, Waltimo-Sirén J, Thesleff I, D'Souza RN. Phenotypic changes in dentition of Runx2 homozygote-null mutant mice. J Histochem Cytochem 2004;52(1):131-139.

[47] Wang XP, Aberg T, James MJ, Levanon D, Groner Y, Thesleff I. Runx2 (Cbfa1) inhibits Shh signaling in the lower but not upper molars of mouse embryos and prevents the budding of putative successional teeth. J Dent Res 2005;84(2):138-143.

[48] Otto F, Thornell AP, Crompton T, Denzel A, Gilmour KC, Rosewell IR, Stamp GW, Beddington RS, Mundlos S, Olsen BR, Selby PB, Owen MJ. Cbfa1, a candidate gene for cleidocranial dysplasia syndrome, is essential for osteoblast differentiation and bone development. Cell 1997;89(5):765-771. [49] Gardner EJ, Richards RC. Multiple cutaneous and subcutaneous lesions occurring simultaneously with hereditary polyposis and osteomatosis. Am J Hum Genet 1953;5(2):139-147.

[50] Chimenos-Küstner E, Pascual M, Blanco I, Finestres F. Hereditary familial polyposis and Gardner's syndrome: contribution of the odonto-stomatology examination in its diagnosis and a case description. Med Oral Patol Oral Cir Bucal 2005;10(5):402-409.

[51] Ramaglia L, Morgese F, Filippella M, Colao A. Oral and maxillofacial manifestations of Gardner's syndrome associated with growth hormone deficiency: case report and literature review. Oral Surg Oral Med Oral Pathol Oral Radiol Endod 2007;103(6):e30-34.

[52] Wijn MA, Keller JJ, Giardiello FM, Brand HS. Oral and maxillofacial manifestations of familial adenomatous polyposis. Oral Dis 2007;13(4):360-365.

[53] Okamoto M, Sato C, Kohno Y, Mori T, Iwama T, Tonomura A, Miki Y, Utsunomiya J, Nakamura $\mathrm{Y}$, White R, et al. Molecular nature of chromosome $5 \mathrm{q}$ loss in colorectal tumors and desmoids from patients with familial adenomatous polyposis. Hum Genet 1990;85(6):595-599.

[54] Groden J, Thliveris A, Samowitz W, Carlson M, Gelbert L, Albertsen H, Joslyn G, Stevens J, Spirio L, Robertson M, et al. Identification and characterization of the familial adenomatous polyposis coli gene. Cell 1991;66(3):589-600.

[55] Heinen CD. Genotype to phenotype: analyzing the effects of inherited mutations in colorectal cancer families. Mutat Res 2010;693(1-2):32-45.

[56] Phelps RA, Broadbent TJ, Stafforini DM, Jones DA. New perspectives on APC control of cell fate and proliferation in colorectal cancer. Cell Cycle 2009;8(16):2549-2556 
[57] Kuraguchi M, Wang XP, Bronson RT, Rothenberg R, Ohene-Baah NY, Lund JJ, Kucherlapati M, Maas RL, Kucherlapati R. Adenomatous polyposis coli (APC) is required for normal development of skin and thymus. PLoS Genet 2006;2(9):e146.

[58] Järvinen E, Salazar-Ciudad I, Birchmeier W, Taketo MM, Jernvall J, Thesleff I. Continuous tooth generation in mouse is induced by activated epithelial Wnt/beta-catenin signaling. Proc Natl Acad Sci U S A 2006;103(49):18627-18632.

[59] Liu F, Chu EY, Watt B, Zhang Y, Gallant NM, Andl T, Yang SH, Lu MM, Piccolo S, Schmidt-Ullrich R, Taketo MM, Morrisey EE, Atit R, Dlugosz AA, Millar SE. Wnt/beta-catenin signaling directs multiple stages of tooth morphogenesis. Dev Biol 2008;313(1):210-224.

[60] Wang XP, O'Connell DJ, Lund JJ, Saadi I, Kuraguchi M, Turbe-Doan A, Cavallesco R, Kim H, Park PJ, Harada H, Kucherlapati R, Maas RL. Apc inhibition of Wnt signaling regulates supernumerary tooth formation during embryogenesis and throughout adulthood. Development 2009;136(11):1939-1949.

[61] Liu F, Dangaria S, Andl T, Zhang Y, Wright AC, Damek-Poprawa M, Piccolo S, Nagy A, Taketo MM, Diekwisch TG, Akintoye SO, Millar SE beta-Catenin initiates tooth neogenesis in adult rodent incisors. J Dent Res 2010;89(9):909-914.

[62] Huysseune A, Thesleff I. Continuous tooth replacement: the possible involvement of epithelial stem cells. Bioessays 2004;26(6):665-671.

[63] Peterková R, Peterka M, Viriot L, Lesot H. Development of the vestigial tooth primordia as part of mouse odontogenesis. Connect Tissue Res 2002;43(2-3):120-128.

[64] Peterková R, Lesot H, Viriot L, Peterka M. The supernumerary cheek tooth in tabby/EDA mice-a reminiscence of the premolar in mouse ancestors. Arch Oral Biol 2005;50(2):219-225.

[65] Peterkova R, Churava S, Lesot H, Rothova M, Prochazka J, Peterka M, Klein OD. Revitalization of a diastemal tooth primordium in Spry2 null mice results from increased proliferation and decreased apoptosis. J Exp Zool B Mol Dev Evol 2009;312B(4):292-308.

[66] Prochazka J, Pantalacci S, Churava S, Rothova M, Lambert A, Lesot H, Klein O, Peterka M, Laudet V, Peterkova R. Patterning by heritage in mouse molar row development. Proc Natl Acad Sci U S A 2010;107(35):15497-15502

[67] Viriot L, Peterková R, Peterka M, Lesot H. Evolutionary implications of the occurrence of two 
vestigial tooth germs during early odontogenesis in the mouse lower jaw. Connect Tissue Res 2002;43(2-3):129-133.

[68] Witter K, Lesot H, Peterka M, Vonesch JL, Mísek I, Peterková R Origin and developmental fate of vestigial tooth primordia in the upper diastema of the field vole (Microtus agrestis, Rodentia). Arch Oral Biol 2005;50(4):401-409.

[69] Keranen SV, Kettunen P, Aberg T, Thesleff T, Jernvall T. Gene expression patterns associated with suppression of odontogenesis in mouse and vole diastema region, Dev. Genes Evol 1999;209(8) : 495-506.

[70] Mustonen T, Pispa J, Mikkola ML, Pummila M, Kangas AT, Pakkasjärvi L, Jaatinen R, Thesleff I. Stimulation of ectodermal organ development by Ectodysplasin-A1. Dev Biol 2003;259(1):123-136. [71] Pispa J, Mustonen T, Mikkola ML, Kangas AT, Koppinen P, Lukinmaa PL, Jernvall J, Thesleff I. Tooth patterning and enamel formation can be manipulated by misexpression of TNF receptor Edar. Dev Dyn 2004;231(2):432-440.

[72] Tucker AS, Headon DJ, Courtney JM, Overbeek P, Sharpe PT. The activation level of the TNF family receptor, Edar, determines cusp number and tooth number during tooth development. Dev Biol 2004;268(1):185-194.

[73] OD. Klein, G. Minowada, R. Peterkova, A. Kangas, BD. Yu, H. Lesot , M. Peterka, J. Jernvall, GR. Martin, Sprouty genes control diastema tooth development via bidirevtional antagonism of epithelial-messenchymal FGF signaling, Dev.Cell 2006;11(2) :181-190.

[73] Ohazama A, Haycraft CJ, Seppala M, Blackburn J, Ghafoor S, Cobourne M, Martinelli DC, Fan CM, Peterkova R, Lesot H, Yoder BK, Sharpe PT. Primary cilia regulate Shh activity in the control of molar tooth number. Development 2009;136(6):897-903.

[74] Zhang Q, Murcia NS, Chittenden LR, Richards WG, Michaud EJ, Woychik RP, Yoder BK. Loss of the Tg737 protein results in skeletal patterning defects. Dev Dyn 2003 ;227(1):78-90.

[75] Kaufman MH, Chang HH, Shaw JP. Craniofacial abnormalities in homozygous Small eye (Sey/Sey) embryos and newborn mice. J Anat 1995;186 ( Pt 3):607-617.

[76]Murashima-Suginami A, Takahashi K, Sakata T, Tsukamoto H, Sugai M, Yanagita M, Shimizu A, Sakurai T, Slavkin HC, Bessho K. Enhanced BMP signaling results in supernumerary tooth formation in USAG-1 deficient mouse. Biochem Biophys Res Commun 2008;369(4):1012-1016. 
[77] Kratochwil K, Dull M, Farinas I, Galceran J, Grosschedl R. Lef1 expression is activated by BMP-4 and regulates inductive tissue interactions in tooth and hair development. Genes Dev 1996;10(11):1382-1394.

[78] Zhou P, Byrne C, Jacobs J, Fuchs E. Lymphoid enhancer factor 1 directs hair follicle patterning and epithelial cell fate. Genes Dev1995;9(6):700-713.

[79] Nakamura T, de Vega S, Fukumoto S, Jimenez L, Unda F, Yamada Y. Transcription factor epiprofin is essential for tooth morphogenesis by regulating epithelial cell fate and tooth number. $\mathrm{J}$ Biol chem 2008;283(8):4825-4833.

[80] Zhang Z, Lan Y, Chai Y, Jiang R. Antagonistic actions of Msx1 and Osr2 pattern mammalian teeth into a single row. Science 2009;323(5918):1232-1234.

[81] Huang B, Takahashi K, Sakata-Goto T, Kiso H, Togo Y, Saito K, Tsukamoto H, Sugai M, Akira A, Shimizu A, Bessho K. Phenotypes of CEBPB Deficiency: Supernumerary Teeth and Elongated Coronoid Process. Oral Dis 2012; in press,

[82] Fang J, Zhu YY, Smiley E, Bonadio J, Rouleau JP, Goldstein SA, McCauley LK, Davidson BL, Roessler BJ. Stimulation of new bone formation by direct transfer of osteogenic plasmid genes. Proc Natl Acad Sci USA 1996;93(12):5753-5758.

[83] Jin Q, Anusaksathien O, Webb SA, Printz MA, Giannobile WV. Engineering of tooth-supporting structures by delivery of PDGF gene therapy vectors. Mol Ther 2004 ;9(4):519-526.

[84] Lander ES, Linton LM, Birren B, Nusbaum C, Zody MC, Baldwin J, Devon K, Dewar K, Doyle M, FitzHugh W, Funke R, Gage D, Harris K, Heaford A, et al. Initial sequencing and analysis of the human genome. Nature 2001;409(6822):860-921.

[85] Takahashi, K., Nuckolls, G.H., Tanaka, O., Semba, I., Takahashi, I., Dashner,R., Shum, L. Slavkin, H.C. Adenovirus mediated ectopic expression of Msx2 in even-numbered rhombomeres cause apoptotic elimination of cranial neural crest cells en ovo. Development 1998;125(9), $1627-1635$.

[86] Takahashi K, Nuckolls GH, Takahashi I, Nonaka K, Nagata M, Ikura T, Slavkin HC and Shum L. Msx2 is a repressor of chondrogenic differentiation in migratory crainal neural crest cells. Dev Dyn 2001, 222(2), 252-262.

[87] Aihara H, Miyazaki J. Gene transfer into muscle by electroporation in vivo. Nat Biotechnol 
1998;16(9):867-870.

[88] Osawa K, Okubo Y, Nakao K, Koyama N, Bessho K. Osteoinduction by microbubble-enhanced transcutaneous sonoporation of human bone morphogenetic protein-2. J Gene Med 2009;11(7):633-641.

[89] Osawa K, Okubo Y, Nakao K, Koyama N, Bessho K. Feasibility of BMP-2 gene therapy using an ultra-fine needle. In: You Y. (ed.) Targets in Gene Therapy. Rijeka:InTech; 2011.p159-166 